\title{
ÜRINER SISTEM ENFEKSIYONU
}

\author{
- Fatma Şemsa ÇAYCI
}

Ankara Şehir Hastanesi, Çocuk Nefroloji Kliniği, Ankara, Türkiye

Uriner sistem enfeksiyonu (ÜSE) çocukluk yaş grubunun en sık karşılaşılan enfeksiyonlarından biridir. 1 ay- 11 yaş çocukların yaklaşık \%8'inin en az bir defa ÜSE olduğu ve bunların da yaklaşık \%30'unun ilk 6 ay 12 ay arasında tekrar ÜSE geçirdiği bilinmektedir (1). Tedavinin hemen başlanması, ürosepsis gibi kısa-dönem ve renal hasar gibi uzun-dönem morbiditenin önlenmesinde önemlidir. Renal hasar, hayatın ilerleyen dönemlerinde hipertansiyon, proteinüri ve kronik böbrek hastalığı gibi komplikasyonlara neden olabilmektedir $(1,2)$. Küçük yaşta ÜSE geçirme, tedavide gecikme, vezikoüreteral reflü (NUR) ve tekrarlayan ÜSE gibi faktörlerin böbrek hasarı riskini artırdığı bilinmektedir (1-3). Teknesyum-99m dimerkaptosüksinik asit (Tc-99M-DMSA) sintigrafisi, ÜSE'nin teşhisi, lokalizasyonu ve renal skar tespiti için en hassas yöntemlerden biridir ancak tek bir Tc-99M-DMSA sintigrafisi ile akut hasarın renal skardan ayırt edilmesi de pek mümkün olamayabilmektedir (3). ÜSE sonrası gelişen renal hasar sıklı̆ı, renal hasarı etkileyen faktörler ile ilgili birçok çalışmaya rağmen, bu lezyonların zaman içinde değişimi hakkında çok fazla veri bulunmamaktadır (1-3).

Dergimizde yayınlanan Kargın Çakııı E ve ark.(4) çalışmasında 143 hastanın ilk ateşli ÜSE'dan en az 90 gün ve 2 yll sonra, Tc-99M-DMSA çekilme sonrası elde edilen verileri retrospektif olarak değerlendirilmiștir. Tc99M-DMSA sintigrafisinde renal hasar tespit edilen 143 hastanın \%18.8'inde bulgularda ilerleme, \%26.5'sında bulgularda gerileme, \%54.5 'inde ise değişiklik olmadığı belirtilmiştir. Cinsiyet veya yaș açısından gruplar arasında fark olmadığı vurgulanırken renal hasarda ilerleme saptanan grupta, yüksek oranda (\%77.8) evre IV-V VUR ve tekrarlayan ÜSE (\%81.5) olduğu bildirilmiştir. Sonuç olarak da renal hasarda ilerleme için tekrarlayan ÜSE'nun bağımsız bir risk faktörü olduğu, bu çocuklarda yüksek dereceli VUR'un saptanma olasilığının yüksek olduğu ve renal hasar derecesinin değerlendirilmesi açısından bu çocukların uzun dönem izlenmesi gerektiği vurgulanmıştır.

\section{KAYNAKLAR}

1. Simões E Silva AC, Oliveira EA, Mak RH. Urinary tract infection in pediatrics: an overview. J Pediatr (Rio J) 2019; 26. pii: S0021-7557(19)30479-6.

2. Kaufman J, Temple-Smith M, Sanci L. Urinary tract infections in children: an overview of diagnosis and management. BMJ Paediatr Open. 2019; 24;3:e000487.

3. Swerkersson S, Jodal U, Sixt R, Stokland EPark YS. Renal scar formation after urinary tract infection in children. Korean J Pediatr 2012;55:367-70.

4. Kargın Çakıcı E, Can Gür G, Kara Eroğlı F, Yazılıtaş F, Güngör T, Çelikkaya E, ve ark. Üriner Sistem Enfeksiyonu Geçiren 1-24 Ay Arası Çocuklarda Renal Hasarın Zamanla Değişiminin Değerlendirilmesi. Türkiye Çocuk Hast Derg 2019;13:41823. 